\title{
Book Reviews:
}

Guy S. Goodwin-Gill, The Refugee in International Law (Clarendon Press, Oxford, 1983), $318 \mathrm{pp}$.

\section{by William Angus}

With the somewhat belated acceptance by Canada in 1969 of the 1951 U.N. Convention relating to the status of refugees, and legislative confirmation first in an amendment to the Immigration Appeal Board Act during the 1973-74 session of Parliament and subsequently in the new Immigration Act, 1976, the potential for Canadian courts, tribunals and lawyers to resort to international law for direction and guidance on refugee law seemed promising. But as noted by Wydrzynski in his recent text on Canadian immigration law and procedure, this development has not occurred for a variety of reasons. One of the inhibiting factors undoubtedly has been the lack of an authoritative common law reference work. GrahlMadsen's classic volumes have been referred to occasionally by Canadian courts, but its civil law style may have contributed to the relative paucity of reliance on it in Canadian legal forums.

In this context, the arrival on the common law scene of Goodwin-Gill's examination of the refugee in international law may be timely and significant. The author is introduced on the jacket as a legal adviser at the Office of the U.N. High Commissioner for Refugees (UNHCR). He explains in his acknowledgements that some of the book's origins lie in his research for the D.Phil. degree at Oxford. Australia provided the setting for its writing, although input from New Zealand sources is also recognized. Thus the work under review has quite strong common law ties from the Commonwealth, which are reflected in its text and footnotes.

Part One of the work commences with a review of events leading up to the definition of the term refugee in the 1951 Convention and the 1967 Protocol, then considers some regional and municipal developments. A chapter analyzing the Convention definition and its application in the determination of refugee status follows. This should be of considerable interest and benefit to lawyers practising before Canadian courts. For example, there is an illuminating discussion on the difficult problem of whether claimants who fear prosecution and punishment for conscientious objection to military service fall within the Convention definition, or whether they are merely in breach of laws of general application and therefore do not quality as Convention refugees. Canadian case law is divided and somewhat confusing on this issue. Recourse to the experience of other legal jurisdictions might prove helpful in resolving our difficulties on the question.

Loss and denial of refugee status and benefits are addressed in the next chapter. Again, examination of this topic is of interest to the Canadian scene. The Immigration Act, 1976 does not ensure that the Convention refugee, once so found, will have a right to remain in Canada. Curiously, he or she must be "lawfully in Canada" in order to have the right to remain. Of course, the refugee has no status in Canadian law on arrival, or if a visitor, must have lost that status in order to initiate a formal refugee claim toward the end of the inquiry proceeding. Attempts in the Boun-Leau and Dmitrovic cases in the Federal Court of Appeal to challenge the offending provision of the Immigration Act, 1976 failed, although the particular facts in these two cases may have dictated a result not inconsistent with international law. Nevertheless, this quirk in our present immigration legislation would seem generally to be contrary to our international obligations. Goodwin-Gill discusses the situations in which voluntary acts of the individual or a change in circumstances will lead to a loss and denial of refugee status and its benefits, setting forth three particular types of undeserving cases. His discussion of these issues should be helpful in arguing against extensions of the Boun-Leau and Dmitrovic cases.

For the Canadian reader, the next two parts of the book may be of less immediate interest. Nevertheless, they provide a focus on the international legal situation of refugees. Part Two covers asylum. It commences with an examination of the principle of non-refoulement, that is, "that no refugee should be returned to any country where he or she is likely to face persecution or danger to life or freedom". In GoodwinGill's view, the evidence supports a conclusion that the non-refoulement principle forms part of general international law. Of particular concern is the admission and non-rejection of a refugee claimant at the frontier of a state. On its face, the Immigration Act, 1976 accommodates the principle of non-refoulement. One might question, however, whether the Canadian policy of instructing its visa officers in other countries not to issue visas to those who might make a refugee claim on arrival in Canada, meets with the spirit and intendment of the principal of nonrefoulement. Goodwin-Gill also examines non-refoulement in the particular situations of extradition, expulsion and illegal entry, recognizing that certain situations will be exceptional and not amount to refoulement.

There follows a chapter on asylum which is essentially an historical review of its origins and development in international instruments and acts, leading up to the failure of the 1977 U.N. Conference to resolve the essential issues. In the penultimate section of this chapter, Goodwin-Gill discusses the intractable problems created by recent large-scale movement of refugees. Essentially the 1951 Convention concerned itself with the individual refugee seeking asylum. Traditional approaches to asylum, although still relevant, have proved to be insufficient in recent years to cope with political and humanitarian problems of refugees on a massive scale. That states in proximity to the source of refugees will now provide temporary asylum, but not a lasting solution, is hardly surprising. Although the principle of non-refoulement may be observed, no easy resolution of the extremely difficult problems created by 